\title{
Сравнение базитовых вулканитов сумия Карелии с базитами расслоенных интрузий и друзитами Беломорья
}

\section{Арестова Н.А., Чекулаев В.П., Кучеровский Г.А.}

Институт геологии и геохронологии докембрия РАН, Санкm-Петербург, narestova2009@rambler.ru, vpchekulaev@mail.ru

Аннотация. Проведено сравнение базитовых вулканитов сумийских структур Карельской провинции с коматиитовыми базальтами Ветреного пояса, базитами расслоенных интрузий и друзитами Беломорской провинции. Показано, что все эти комплексы образованы в узкий интервал времени 2.4-2.5 млрд. лет назад. Все базиты этого времени близки по химическому составу: $\mathrm{MgO}=15.5-5$ \% $\mathrm{mg} \#=0.65-0.49, \mathrm{TiO}_{2}>0.5 \%$, отношения $\mathrm{Ti} / \mathrm{Zr}=50-80, \mathrm{Zr} / \mathrm{Y}=3-6$. Они обогащены ЛР3Э с $(\mathrm{La} / \mathrm{Yb})_{\mathrm{N}}=5-10,(\mathrm{La} / \mathrm{Sm})_{\mathrm{N}}=2.5-3.5,(\mathrm{Gd} / \mathrm{Yb})_{\mathrm{N}}=1.2-2.0$, $\mathrm{Nb} / \mathrm{La}<1$. Для них характерно низкое отношение ${ }^{147} \mathrm{Sm} /{ }^{144} \mathrm{Nd}=0.10-0.14$ и значение $\varepsilon_{\mathrm{Nd}}(2.45)$ от 0.2 до -2.5 . Сходные геохимические и изотопные характеристики различных типов базитов и близкий возраст свидетельствуют о сходном или едином процессе образования их расплавов и последующей контаминации древней корой на 2-15 \%. Незначительные различия обусловлены локализацией расплавов в доменах с различной коровой предысторией. Геодинамическую обстановку формирования сумийских базитов Карелии расслоенных интрузий и друзитов Беломорья следует рассматривать как внутриконтинентальный рифтинг.

Ключевые слова: Ранний протерозой, Карельская провинция, базитовые вулканиты сумия.

\section{The comparison of the Karelian Sumian basite volcanites with basites of layered intrusions and the White Sea drusites}

\author{
Arestova N.A., Chekulaev V.P., Kucherovsky G.A. \\ Institute of Precambrian Geology and Geochronology RAS, St.-Petersburg, narestova2009@rambler.ru, \\ vpchekulaev@mail.ru
}

\begin{abstract}
The comparison of basite volcanites of Sumian structures from the Karelia province with komatiite basalts of the Vetreny Belt, basites of layred intrusions and druzites of the White Sea province is carried out. It is shown that all these complexes were formed in a narrow time interval of 2.4-2.5 Ga. All basites of this time have a similar chemical composition: $\mathrm{MgO}=15.5-5 \%, \mathrm{mg} \#=0.65-0.49, \mathrm{TiO}_{2}>0.5 \%, \mathrm{Ti} / \mathrm{Zr}=50-80, \mathrm{Zr} / \mathrm{Y}=3-6 . \mathrm{They}$ are enriched with LREE with $(\mathrm{La} / \mathrm{Yb})_{\mathrm{N}}=5-10,(\mathrm{La} / \mathrm{Sm})_{\mathrm{N}}=2.5-3.5,(\mathrm{Gd} / \mathrm{Yb})_{\mathrm{N}}=1.2-2.0, \mathrm{Nb} / \mathrm{La}<1$. They are characterized by a low ratio of ${ }^{147} \mathrm{Sm} /{ }^{144} \mathrm{Nd}=0.10-0.14$ and a value of $\varepsilon_{\mathrm{Nd}}(2.45)$ from 0.2 to -2.5 . Similar geochemical and isotopic characteristics of different types of basites and their close age indicate a similar or uniform process of formation of their melts and subsequent contamination by the ancient crust by $2-15 \%$. Minor differences occurred due to the localization of melts in domains with different crust histories. The geodynamic situation of the formation of the Karelian Sumian basites of of layered intrusions and drusites of the White Sea region should be considered as an intra-continental rifting.

Key words: Paleoproterozoic, Karelia province, basite volcanites of the Sumian structures.
\end{abstract}

Супракрустальные образования раннего (доятулийского) протерозоя, т.е. располагающиеся в стратиграфической шкале докембрия между лопием и ятулием, присутствуют в Карельской и Кольско-Норвежской провинциях Балтийского щита. На территории Карельской провинции они известны в 24 структурах различного размера. Сумийские базитовые вулканиты варьируют по составу от коматиитовых базальтов до андезито-базальтов, и объединены термином «базальты». В настоящее время в Карельской провинции выполнено около 20 определений возраста базитовых вулканитов и одновозрастных с ними кислых вулканитов как классическим U-Pb методом по циркону, так и по единичным зернам циркона на ионном микрозонде SHRIMP II и Sm-Nd методом (Буйко и др., 1995, Злобин и др., 2010, Левченков и др., 1994, Мыскова и др., 2013 и др.). Все полученные значения возраста находятся в узком интервале времени 2407-2445 млн. лет. Такой же возраст имеют коматиитовые базальты Ветреного пояса (Puchtel et al., 1997, 2016), базиты крупных расслоенных интрузий, к которым в Карельской провинции относятся Бураковская интрузия, интрузии Олангской гуппы (Amelin et al., 1995, Семенов и др 1995, Шарков др., 1995, Николаев,1995 ) и интрузии груп- 
пы Койлисма в Финляндии (Alapieti, 1982), а также друзиты Беломорской провинции (Bogdanova, Bibikova, 1993; Aleksejev et al., 2000; Кудряшов, 1999 и др.). Таким образом, базиты с возрастом 2.4-2.5 млрд. лет развиты на значительной территории архейской части щита. Нашей основной задачей явилось изучение базальтов и андезитобазальтов сумийских структур, сопоставление их с одновозрастными коматиитовыми базальтами Ветреного пояса и базитами расслоенных интрузий Карельской провинции, для выявления на основе сходств и различий их исходных составов, сходств и различий в условиях образования и преобразования их первичных расплавов. Предполагается также выявить сходства и различия в геодинамической обстановке образования и локализации базальтов и интрузивных базитов сумийского возраста Карельской и Беломорской провинций.

Все базальты и интрузивные базиты возраста 2.4-2.5 мдрд. лет отличает повышенное на 2-4 \% содержание $\mathrm{SiO}_{2}$ по сравнению с коматиитами и базальтами мезо- и неоархея (Lobach-Zhuchenko et al., 1998; Арестова, Глебовицкий, 2005; Чекулаев Арестова, 2018). В раннепротерозойских базитах $\mathrm{MgO}=16-5 \%, \mathrm{mg} \#=0.63-0.49$, концентрации $\mathrm{TiO}_{2}$ в большинстве образцов превышают $0.5 \%$ (табл. 1), тогда как в мезо- и неоархейских $\mathrm{MgO}=31.5-5 \%, \mathrm{mg \#}=0.81-0.49$. Все базиты возраста 2.4-2.5 мдрд. лет обогащены $\mathrm{Zr}$ и ЛРЗЭ, имеют низкие отношения $\mathrm{Ti} / \mathrm{Zr}(50-80)$ и высокие $\mathrm{Zr} / \mathrm{Y}$ (3-6). Они характеризуются $(\mathrm{La} / \mathrm{Yb})_{\mathrm{N}}=5-10,(\mathrm{La} / \mathrm{Sm})_{\mathrm{N}}=2.5-3.5,(\mathrm{Gd} / \mathrm{Yb})_{\mathrm{N}}=1.2-2.0$, отрицательными аномалиями $\mathrm{Nb}(\mathrm{Nb} / \mathrm{La}<1)$, Р и положительными аномалими $\mathrm{Pb}$ (табл.1).

В большей части базитовых вулканитов и в их интрузивных аналогах установлено разделение исходных расплавов на магнезиальную и железистую серии. В сумийских вулканитах этот процесс фиксируется наличием вариолитов с более магнезиальнми вариолями в более железистой матрице, в друзитах и расслоенных базитовых интрузиях - присутствием прослоев железистых габбро в магнезиальных (табл. 1). Распределение Р3Э, Тi и Zr в магнезиальной и железистой частях базитов соответствует таковому в породах, образованных при жидкостной дифференциацеи их исходных расплавов (Watson, 1976; Lobach-Zhuchenko et al., 1998; Арестова, Глебовицкий, 2005). Процесс жид-

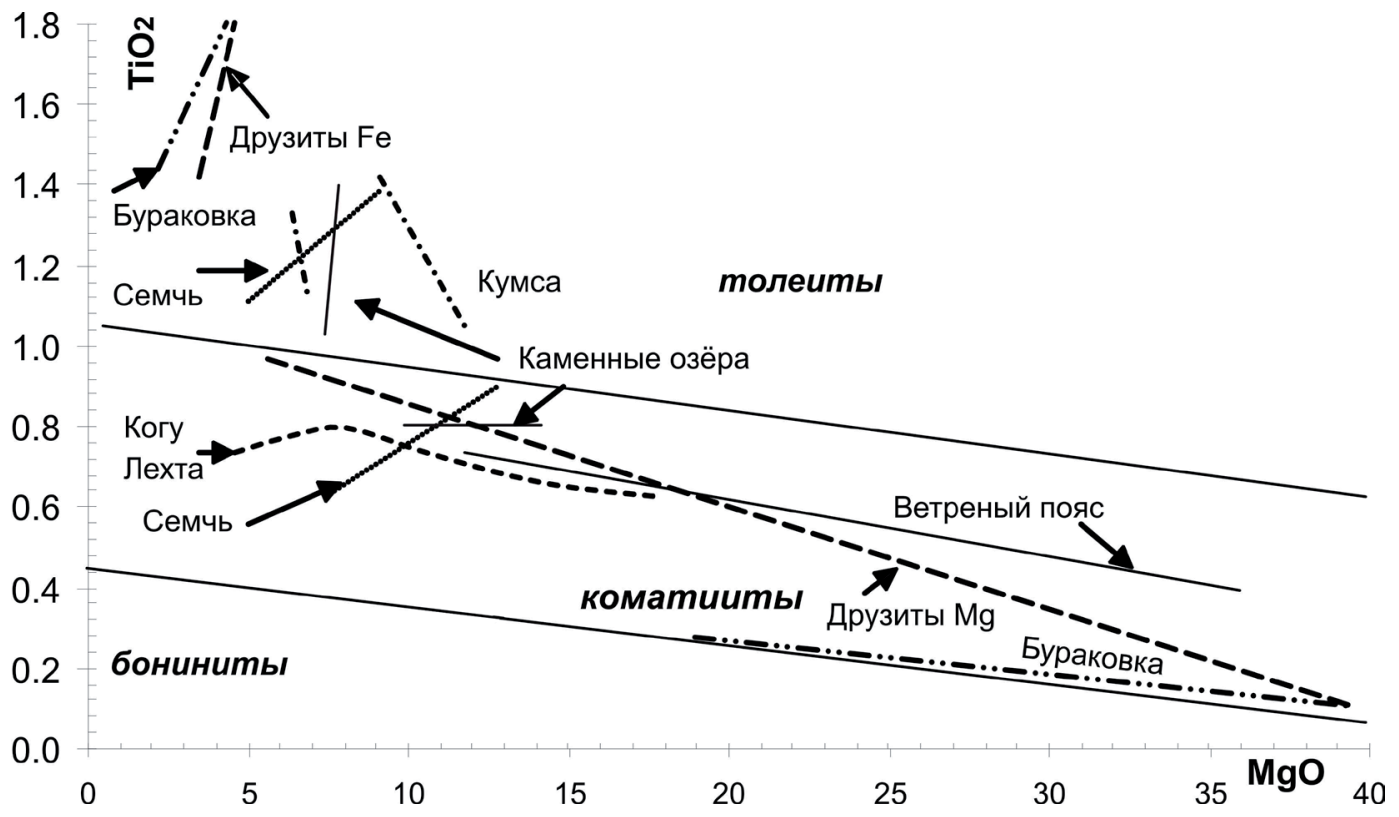

Рис. 1. Диаграмма $\mathrm{MgO}-\mathrm{TiO}_{2}$ (вес. \%) с трендами составов пород магнезиальной и железистой серий базитовых вулканитов ряда сумийских структур в сравнении с трендами расслоенных интрузий Карельской провинции и друзитами Беломорья. Тренды составов базитов построены по данным авторов, указанных в примечаниях к таблице 1.

Fig. 1. $\mathrm{TiO}_{2}-\mathrm{MgO}$ (wt. \%) diagram for the Sumian basite volcanics, layred intrusions of the Karelian province and drusites of the White Sea province. Trends of the basite compositions are based on the authors' data indicated in the notes to Table 1. 


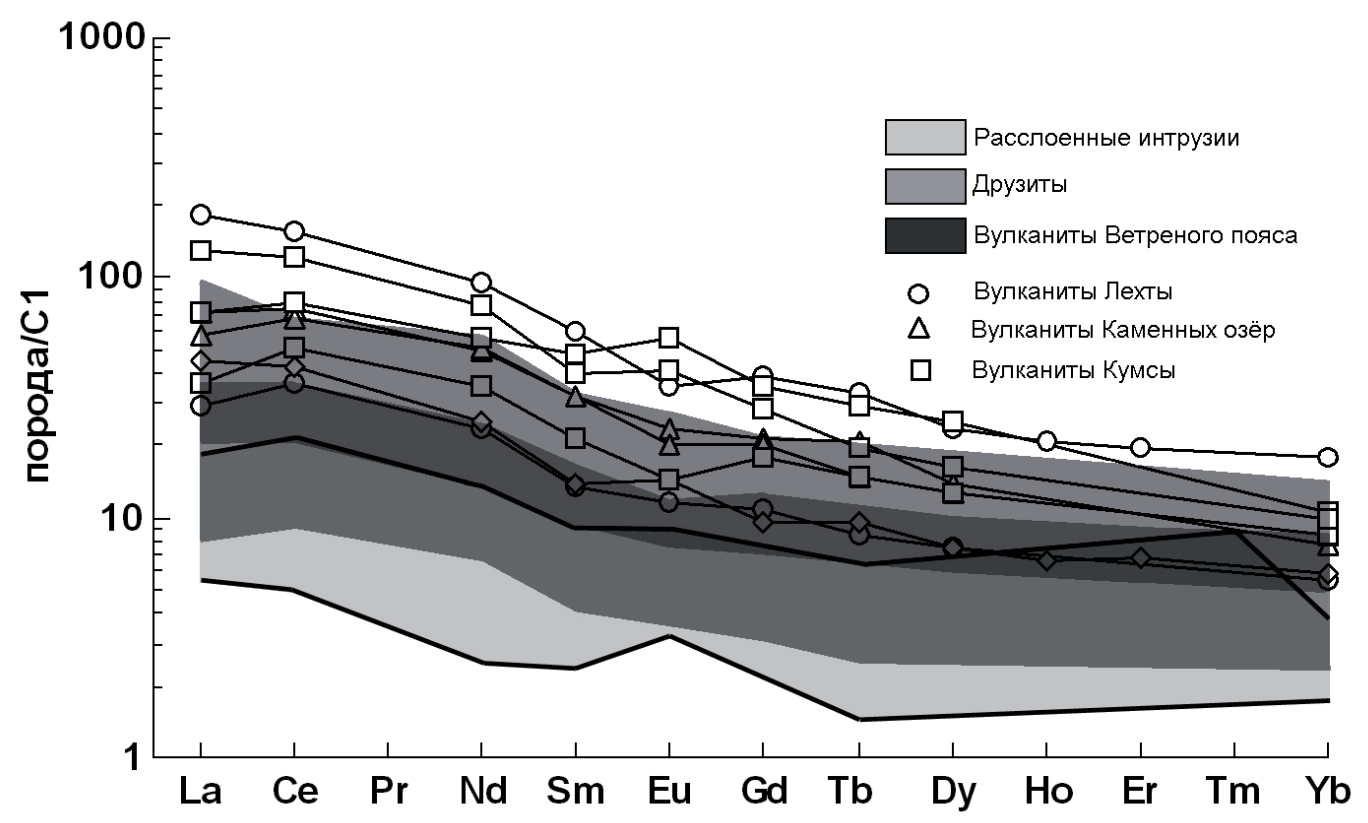

Рис. 2. Распределение РЗЭ нормализованных на С1 в базальтовых вулканитах сумия (неопубликованные данные авторов) Ветреного пояса Карелии (Puchtel et al., 1997, 2016) расслоенной интрузии Портиваара гр. Койлисма (Alapieti, 1982) и друзитах Беломорья (Lobach-Zhuchenko et al., 1998; Арестова, Глебовицкий, 2005).

Fig. 2. Chondrite-normalized REE abundances in the Sumian basalts volcanics (the authors' unpublished data) of the Karelian Vetreny belt (Puchtel et al., 1997, 2016), layered intrusions of the Portivaara block, the Kojlisma massive (Alapieti, 1982) and the White Sea drusites (Lobach-Zhuchenko et al., 1998; Arestova, Glebovitsky, 2005).

костной дифференциации единого исходного расплава подтверждается также результатами математического моделирования образования расслоенности в интрузиях (Котов, 1998). Сравнение составов сумийских вулканитов и вулканитов Ветреного пояса с интрузивными аналогами на диаграммах Харкера показало, что на диаграмме $\mathrm{MgO}-\mathrm{TiO}_{2}$ составы всех пород располагаются в поле коматиитовой и реже толеитовой серии (рис. 1). Тренды составов базальтов сумийских структур совпадают или продолжают тренды вулканитов Ветреного пояса, друзитов магнезиальной серии и магнезиальных базитов интрузий. Тренды составов вулканитов Семченской, Каменнозерской, и Кумсинской структур, которые принадлежат толеитовой серии, сопоставимы с трендами составов железистой серии друзитов и железистых прослоев в Бураковской интрузии.

Распределения Р3Э сумийских вулканитов аналогичны таковым базальтов и коматиитовых базальтов Ветреного пояса. Концентрации РЗЭ в базальтах Лехтинской структуры аналогичны таковым вулканитов Ветреного пояса, тогда как в базальтах остальных структур сумма РЗЭ выше. Вариации содержаний РЗЭ в породах друзитового комплекса как магнезиальной, так и железистой серии (Lobach-Zhuchenko et al., 1998; рис. 8) полностью соответствуют таковым в базальтах сумийских структур. Базиты расслоенных интрузий имеют близкое к вулканитам и друзитам отношение $\mathrm{La} / \mathrm{Yb}$ (4-8), но в большинстве интузивных пород установлены более низкие концентрации РЗЭ. Распределение редких и РЗ элементов на спайдер-диаграммах демонстрирует идентичность базальтов сумийских структур с базальтами Ветреного пояса, габбро расслоенных интрузий и друзитами Беломорского блока (рис. 2).

Для всех базитов Балтийского шита с возрастом 2.5-2.4 млрд. лет характерно низкое отношение ${ }^{147} \mathrm{Sm} /{ }^{144} \mathrm{Nd}=0.10-0.14$, у вулканитов Ветреного пояса это отношение наиболее выдержанное. Более существенные колебания наблюдаются в вулканитах Каменнозерской структуры, где ${ }^{147} \mathrm{Sm} /{ }^{144} \mathrm{Nd}=0.10-0.15$. Все базиты данного этапа имеют преимущественно отрицательные значения $\varepsilon_{\mathrm{Nd}}(2.45)$ от 0.2 до -2.5 . 
Таблица 1. Средние составы базитовых вулканитов ряда сумийских структур, базитов расслоенных интрузий Карельской провинции и друзитов Беломорья.

Table 1. The average composition of basic volcanic rocks of the Sumian structures, basic rocks of layered intrusions of the Karelia province, and the White Sea drusites.

\begin{tabular}{|c|c|c|c|c|c|c|c|c|c|c|c|c|}
\hline \multirow{3}{*}{ 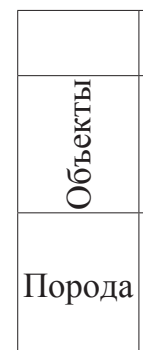 } & \multicolumn{8}{|c|}{ Вулканиты } & \multirow{2}{*}{\multicolumn{2}{|c|}{$\begin{array}{l}\text { Друзиты } \\
\text { Беломорье }\end{array}$}} & \multicolumn{2}{|c|}{$\begin{array}{c}\text { Расслоенные } \\
\text { интрузии }\end{array}$} \\
\hline & \multicolumn{2}{|c|}{ Каменные озёра } & \multicolumn{2}{|c|}{ Кумса } & \multicolumn{2}{|c|}{ Лехта } & \multirow{2}{*}{\begin{tabular}{|}
$\begin{array}{c}\text { Суна- } \\
\text { Семчь }\end{array}$ \\
Андези- \\
базальт
\end{tabular}} & \multirow{2}{*}{$\begin{array}{c}\text { Ветре- } \\
\text { ный пояс } \\
\begin{array}{c}\text { Комат. } \\
\text { базальт }\end{array}\end{array}$} & & & $\begin{array}{c}\text { Порти- } \\
\text { ваара } \\
\text { зона за- }\end{array}$ & $\begin{array}{l}\text { Бура- } \\
\text { ковка }\end{array}$ \\
\hline & $\begin{array}{c}\text { Вариоли } \\
\text { базальт }\end{array}$ & $\begin{array}{c}\text { Матрица } \\
\text { андези- } \\
\text { базальт. }\end{array}$ & 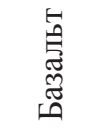 & $\begin{array}{c}\text { Андези- } \\
\text { базальт }\end{array}$ & 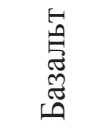 & $\begin{array}{c}\text { Андези- } \\
\text { базальт }\end{array}$ & & & $\begin{array}{l}\mathrm{Mg}- \\
\text { серия }\end{array}$ & $\begin{array}{c}\mathrm{Fe}- \\
\text { серия }\end{array}$ & & \\
\hline $\mathrm{SiO}_{2}$ & 51.31 & 55.07 & 52.26 & 54.46 & 48.31 & 57.11 & 55.90 & 49.68 & 50.98 & 52.74 & 46.78 & 50.94 \\
\hline $\mathrm{TiO}_{2}$ & 0.81 & 1.04 & 1.23 & 1.23 & 0.70 & 0.83 & 1.05 & 0.58 & 0.57 & 1.34 & 0.30 & 0.64 \\
\hline $\mathrm{Al}_{2} \mathrm{O}_{3}$ & 10.21 & 13.29 & 10.81 & 12.81 & 13.93 & 15.91 & 13.77 & 10.80 & 11.30 & 12.73 & 17.26 & 11.64 \\
\hline $\mathrm{FeO}$ & 10.91 & 10.69 & 13.28 & 11.38 & 13.51 & 9.60 & 10.87 & 12.09 & 9.83 & 13.96 & 7.37 & 9.59 \\
\hline $\mathrm{MnO}$ & 0.15 & 0.16 & 0.19 & 0.16 & 0.21 & 0.14 & 0.17 & 0.18 & 0.16 & 0.15 & 0.13 & 0.14 \\
\hline $\mathrm{MgO}$ & 9.91 & 6.75 & 7.96 & 5.05 & 9.67 & 6.72 & 5.71 & 15.85 & 14.49 & 5.06 & 12.35 & 16.26 \\
\hline $\mathrm{CaO}$ & 8.73 & 8.44 & 7.66 & 7.31 & 9.48 & 5.68 & 6.32 & 8.50 & 7.86 & 8.29 & 7.76 & 8.04 \\
\hline $\mathrm{Na}_{2} \mathrm{O}$ & 2.71 & 1.96 & 3.62 & 4.36 & 3.16 & 3.02 & 3.89 & 1.88 & 1.97 & 2.74 & 2.35 & 2.33 \\
\hline $\mathrm{K}_{2} \mathrm{O}$ & 1.59 & 1.17 & 0.68 & 0.85 & 0.93 & 0.89 & 1.53 & 0.36 & 0.81 & 1.22 & 0.75 & 0.38 \\
\hline $\mathrm{P}_{2} \mathrm{O}_{5}$ & 0.14 & 0.15 & 0.15 & 0.18 & 0.09 & 0.13 & 0.14 & 0.08 & 0.07 & 0.06 & & 0.03 \\
\hline $\mathrm{mg}$ & 0.56 & 0.52 & 0.52 & 0.44 & 0.55 & 0.55 & 0.48 & 0.68 & 0.70 & 0.40 & 0.68 & 0.75 \\
\hline $\mathrm{Rb}$ ppm & 43.3 & 18.3 & 13.9 & 16.2 & 15.0 & 25.5 & 34.5 & 8.6 & 22 & 29 & & \\
\hline $\mathrm{Sr}$ & 243 & 327 & 154 & 313 & 180 & 170 & 251 & 149 & 191 & 244 & 221 & \\
\hline $\mathrm{Ba}$ & 373 & 369 & 135 & 268 & 248 & 197 & 272 & 258 & 227 & 316 & & \\
\hline $\mathrm{Y}$ & 14.7 & 16.0 & 16.7 & 22.7 & 11.4 & 14.16 & 14.9 & 13.3 & 13 & 20 & & \\
\hline $\mathrm{Zr}$ & 115 & 131 & 106 & 116 & 75 & 113 & 121 & 54 & 61 & 99 & & \\
\hline $\mathrm{Hf}$ & 3.11 & 3.22 & 3.34 & 3.07 & 1.47 & 2.29 & 3.32 & 1.54 & H.O & H.O & & \\
\hline $\mathrm{Nb}$ & 6.05 & 8.04 & 6.52 & 10.21 & 3.01 & 4.30 & 7.69 & 1.93 & 5 & 7 & & \\
\hline $\mathrm{Ta}$ & 1.91 & 1.33 & 1.06 & 1.05 & 0.84 & 0.85 & 0.56 & 0.15 & H.O & H.O & & \\
\hline $\mathrm{Pb}$ & 7.5 & 8.7 & 9.5 & 9.25 & & & 7.67 & 3.80 & 12 & 12 & & \\
\hline Th & 3.66 & 4.44 & 5.08 & 3.32 & 1.77 & 2.85 & 3.32 & 2.06 & & & & \\
\hline $\mathrm{U}$ & 0.91 & H.O & 0.53 & 0.83 & 0.45 & 0.81 & 0.78 & 0.44 & & & & \\
\hline $\mathrm{Ti}$ & 5381 & 5730 & 6087 & 6231 & 4132 & 4358 & 6095 & 3376 & 3420 & 6220 & 3000 & 3800 \\
\hline $\mathrm{Cr}$ & 611 & 393 & 379 & 41 & 479 & 71 & 45 & 1279 & 1383 & 123 & 1540 & 2000 \\
\hline $\mathrm{Ni}$ & 230 & 178 & 154 & 62 & & & 113 & 381 & 480 & 49 & 780 & 1000 \\
\hline $\mathrm{Co}$ & 70 & 53 & 45 & 34 & 32 & 106 & 47 & 70 & 61 & 56 & 111 & \\
\hline $\mathrm{V}$ & 223 & 184 & 187 & 204 & 149 & 122.72 & 163 & 196 & 170 & 552 & 100 & \\
\hline $\mathrm{La}$ & 19.3 & 16.0 & 10.0 & 27.3 & 6.35 & 10.37 & 17.4 & 8.53 & 8.2 & 17.5 & 5 & \\
\hline $\mathrm{Ce}$ & 46.0 & 41.5 & 31.5 & 61.6 & 17.89 & 20.73 & 39.2 & 18.93 & 19.2 & 44.3 & 13 & \\
\hline $\mathrm{Pr}$ & & & & & & & 5.05 & & & & & \\
\hline $\mathrm{Nd}$ & 23.2 & 24.2 & 17.0 & 31.7 & 9.65 & 9.86 & 20.6 & 9.87 & 9.7 & 17.3 & 6.5 & \\
\hline $\mathrm{Sm}$ & 4.98 & 4.85 & 3.29 & 6.67 & 1.92 & 2.01 & 3.87 & 2.18 & 2.5 & 4.6 & 1.4 & \\
\hline $\mathrm{Eu}$ & 1.35 & 1.16 & 0.84 & 2.81 & 0.61 & 0.52 & 1.18 & 0.63 & 0.67 & 0.31 & 0.52 & \\
\hline $\mathrm{Gd}$ & 4.47 & 4.09 & 3.69 & 6.48 & 2.04 & 1.89 & 3.95 & 2.19 & 1.85 & 4.25 & & \\
\hline $\mathrm{Tb}$ & 0.73 & 0.53 & 0.52 & 0.88 & 0.27 & 0.3 & 0.55 & & 0.3 & 0.69 & 0.23 & \\
\hline Dy & 3.55 & 3.26 & 3.21 & 5.2 & 1.79 & 1.89 & 3.12 & 2.20 & & & & \\
\hline $\mathrm{Yb}$ & 1.33 & 1.44 & 1.45 & 1.73 & 1.04 & 0.8 & 1.34 & 1.24 & 1.09 & 2.29 & 0.65 & \\
\hline $\mathrm{Lu}$ & 0.36 & 0.2 & 0.26 & 0.31 & 0.17 & 0.12 & 0.20 & & & & 0.16 & \\
\hline $\mathrm{n} 1 / \mathrm{n} 2$ & $2 / 2$ & $3 / 3$ & $2 / 2$ & 4 & $4 / 4$ & $5 / 5$ & $10 / 10$ & $8 / 8$ & $45 / 11$ & $29 / 3$ & $18 / 6$ & $16 /-$ \\
\hline
\end{tabular}


Примечание. Для вычисления средних составов вулканитов Кумсинской, Каменноозерской, Семченской и Лехтенской структур использованы неопубликованные данные авторов, для вулканитов Ветреного пояса (Puchtel et al., 1997, 2016), для друзитов (Lobach-Zhuchenko et al., 1998, Арестова, Глебовицкий, 2005) Средние составы интрузий группы рассчитаны Койлисма по данным (Alapieti, 1982) Бураковской (Николаев и др., 1995, Семёнов и др., 1995). Количество анализов главных (n1), РЭ и Р3Э (n2).

Сопоставление базитов этапа 2.5-2.40 млрд. лет и анализ их распространённости показывает, что в это время на площади щита распространены породы со сходными геохимическими и изотопными характеристиками, локализованные в виде крупных расслоенных интрузий Карелии, роёв даек, мелких многочисленных интрузий друзитов Беломорья и сумийских коматиитов и базальтов. Подобное сходство составов подразумевает единые или, по крайней мере, сходные условия генерации исходных расплавов. Обогащённость всех мафитов этого временного этапа лёгкими РЗЭ, высокие концентрации $\mathrm{Ni}$ свидетельствуют скорее о плюмовой природе их исходных расплавов (Сатрbel and Griffiths, 1992). Присутствие среди вулканитов этого времени коматиитов Ветреного пояса с концентрациями $\mathrm{MgO}$, достигающими $20 \%$ и соответственно с температурой ликвидуса $1400^{\circ} \mathrm{C}$, показывает что температура источника плавления превышала $1600^{\circ} \mathrm{C}$. Следовательно температура плавления источника для коматиитов Ветреного пояса была примерно на $100^{\circ} \mathrm{C}$ выше температуры раннепротерозойской мантии, и для образования подобных расплавов был необходим дополнительный приток тепла, который мог быть обеспечен подъемом плюмов. Геохимические особенности базитов этого этапа свидетельствуют о контаминации плюмовых расплавов веществом коры, которое составляло для разных базитов от 2 до 15 \% (Puchtel et al., 1997; Lobach-Zhuchenko et al., 1998 и др.)

Вопрос о геодинамической обстановке образования расплавов сумийских вулканитов является дискуссионным. Изучение коматиитов Ветреного пояса, относимых к тому же стратиграфическому уровню позволило И.С. Пухтелю с коллегами (Puchtel et al., 1997, 2016) рассматривать эти раннепротерозойские вулканиты как продукт плюмового магматизма, исходные расплавы которого контаминированы на 2 \% древними (3.24 млрд. лет) тоналитами Водлозерского домена. Исследователи раннепротерозойских базитовых инрузий Балтийского щита (Amelin et al., 1995, Семенов и др 1995, Шарков и др., 1995 Bayanova et al., 2009 и др.) связывают их образование с плюмовым магматизмом, который достигал наибольшей активности 2500-2400 млн. лет назад, образуя обширную изверженную провинцию (LIP) площадью около 200000 км². Наши более ранние исследования друзитов Беломорья (Lobach-Zhuchenko et al., 1998) также привели нас к выводу о плюмовой природе их исходных расплавов и последующей контаминации гранитами коры или смешении с расплавами деплетированной литосферной мантии (Lobach-Zhuchenko et al., 1998; Арестова, Глебовицкий, 2005). Для базальтов ряда сумийских структур Центральной Карелии высказано предположение об их образовании в субдукционной обстановке в условиях активной континентальной окраины (Голубев и др., 2002; Светов и др., 2003, и др.). Однако, рядом исследователей ставится под сомнение возможность одновременного существования плюма и островодужных обстановок (Bedard, 2013).

Некоторые различия в составе, которые наблюдаются в базитах с возрастом 2.4-2.5 млрд. лет, объясняются условиями локализации исходных расплавов в доменах Балтийского щита с различной коровой предысторией и, как следствие, различными условиями их последующего преобразования и кристаллизации. Раннепротерозойский плюм привел к образованию крупных расслоенных интрузий и преимущественно линейных вулканических структур, возникших в результате растяжения коры над поднимающимся плюмом. Геодинамическую обстановку формирования палеопротерозойских базитов, как интрузий так и вулканитов Балтийского щита следует рассматривать как внутриконтинентальный рифтинг.

Работа выполнена в рамках темы НИР ИГГД РАН 0153-2019000 1. Авторы благодарят рецензента за внимательное прочтение рукописи и сделанные замечания. 


\section{Литература}

1. Арестова Н.А., Глебовицкий В.А. Магматизм этапа 2.46-2.40 млн. лет // Ранний докембрий Балтийского щита. (Ред. Глебовицкий В.А). С.-Пб.: Наука. 2005. С. 229-243.

2. Буйко А.К., Левченков О.А., Турченко С.И., Друбецкой Е.Р. Геология и изотопное датирование Раннепротерозойского сумийско-сариолийского комплекса Северной Карелии (Паанаярви-Ципрингская структура) // Стратиграфия. Геол. Корреляция. 1995. Т. 3. № 4. С. 16-30.

3. Голубев А.И., Светов С.А., Светова А.И. Сумийские (2.55-2.40 млрд. лет) андезибазальтовые ассоциации центральной Карелии. Электронный Журнал. Исследовано в России. 2002. 081. С. 903-910.

4. Злобин В.Л., Богина М.М., Минц М.В., Бережная Н.Г., Пресняков С.Л., Падерин И.П., Дорофеев Р.О. Граница архей-палеопротерозой на Карельском кратоне: первые U-Pb данные по цирконам из мафитовых вулканитов, полученные на ионном зонде SHRIMP-II // Докл. РАН. 2010. Т. 435. № 1. C. 64-68.

5. Котов С.Р. Струтура контрастной расслоенности «критических» зон базит-гипербазитовых интрузий Кивакка и Бушвельд: свойства, происхождения. Автореферат кадидатской диссертации. С.-Пб. 1998. 21 с.

6. Кудряшов Н.М., Балаганский В.В. Возраст друзитового массива Жемчужный. Беломорский регион России: U-Pb изотопные данные и геологические следствия / Рифтогенез, магматизм, металлогения докембрия. Корреляция геологических комплексов Фенноскандии // Матер. Междун. конференции. Петрозаводск. 1999. С. 78-79.

7. Левченков О.А., Николаев А.А., Богомолов Е.С., Яковлева С.З. Уран-свинцовый возраст кислых магматитов сумия Северной Карелии // Стратиграфия. Геологическая корреляция. 1994. Т. 2. № 1. С. 3-9.

8. Мыскова Т.А., Иванов Н.М., Корсакова М.А., Милькевич Р.И., Бережная Н.Г., Пресняков С.Л. Геология, геохимия и возраст вулканитов тунгудской свиты: к вопросу о границе архей-протерозой в Северной Карелии // Стратиграфия. Геологическая корреляция. 2013. Т. 21. № 4. С. 3-25.

9. Николаев Г.С., Копев-Дворников Е.В., Ганин М.Ф., Гриневич Н.Г. Структуры Бураковско-Аганозерской расслоенной интрузии и распределения в них главных элементов //Отечественная геология. 1995. Т. 10. С. 56-64.

10. Светов С.И., Светова А.И., Назарова Т.Н. Корреляционные реперные уровни в верхнеархейском Хаутаваара-Койкарском стратотипе // Геология и полезные ископаемые Карелии. Петрозаводск. 2003. Вып. 6. С. 3-12.

11. Семенов В.С., Копев-Дворников Е.В., Берковский А.Н., Киреев Б.С., Пчелинцева Н.Ф., Васильева М.О. Расслоенный троктолит-габбро-норитовый интрузив Ципринга: геологическое строение, петрологические выводы // Петрология. 1995. Т. 3. № 6. С. 645-668.

12. Чекулаев В.П., Арестова Н.А. Гетерогенность строения Карельской провинции Фенноскандинавского щита как отражение условий корообразования от палео- до неоархея // Эволюция вещественного и изотопного состава докембрийской литосферы. (Ред. В.А. Глебовицкий и Ш.К. Балтыбаев). С.Пб.: Издательско-полиграфическая ассоциация высших учебных заведений. 2018. С. 35-61.

13. Шарков Е.В., БогатиковО.А., Пчелинцева Н.Ф., Копев-Дворников Е.В., Семенов В.С., Гроховская Т.Л., Николаев Г.С., Чистяков А.В. Песпективы платиноносности раннепротерозойского Бураковского расслоенного интрузива в Южной Карелии // Платина России. Т. 2. М. Геоинформ. 1995. С. 10-19.

14. Alapieti T.The Koillismaa layred igneous cjmplex, Finland - its structure, mineralogy and geochemisty with emphasis on the distribution of chromium // Bull. Geol. Surv. Finl. 1982. N. 319. 116 pp.

15. Alexejev N.L., Zinger T.F., Belyatsky B.V., Balagansky V.V. Age of the crystallization metamorphism of the Pezhostrov gabbro-anorthosites, northen Karelia, Russia// Abstracts of SVEKALAPKO. EUROROBE project. Lammi. Finland. 2000. P. 3.

16. Amelin Yu. V., Heaman L.M., Semenov V.S. U-Pb geochronology of layered mafic intrusions in the eastern Baltic Shield: implications for the timing and duration of Paleoproterozoiccontinental rifting // Precambrian Res. 1995. V. 75. P. 31-46.

17. Bayanova T., Ludden J., Mitrofanov F. Timing and duration of Paleoproerozoic events producing ore-bearing layred intrusions of the Baltic Shield: metallogenic, petrological and geodynamic implications // Geol. Soc. London. S.P. 2009. V. 323. P. 165-198.

18. Bedard J.H. How many arcs can dance on the head of a plume// Precambrian Res. 2013. S.I. V. 229 P. $189-198$.

19. Bogdanova S.V., Bibikova E.V. The «saamian» of the Belomorian Mobile Belt: new geochronological constraints // Precambrian Res. 1993. V. 64. №. 1/4. P. 131-152.

20. Campbell T.H., Griffiths R.W. The changing nature of mantle hotspots through tine: implication for the chemical evolution of the mantle // J. Geol. 1992. V. 100. P. 497-523.

21. Lobach-Zhuchenko S.B., Arestova N.A., Chekulaev V.P., Levsky L.K., Bogomolov E.S., Krylov I.N. Geochemistry and petrology of 2.40-2.45 Ga magmatic rocks in the north-western Belomorian Belt, Fennoscandian Shield, Russia // Precamb. Res. 1998. V. 92. N. 3. P. 223-250. 
22. Puchtel I.S., Haase K.N., Hofmann A.W., Chanvel C., Kulikov V.S., Garbe-Schonberg C.-D., Nemchin A.A. Petrology and geochemistry of crustally contaminated komatiitic basalts from the Vetreny Belt, southeastern Baltic Shield: evidence for an early Proterozoic mantle plume beneath rifted Archean continental lithosphere // Geochim. Cosmochim. Acta. 1997. V. 61. P. 1205-1222.

23. Puchtel I.S., Toubol M , Blichert-Toft J. Walker R.J., Brandon A.D., Nicklas R.W., Kulikov V.S., Samsonov A.V. Lithophile end siderophile element systematic of Eartth`s mantle at the Archean-Proterozoic boundary: evidence from 2/4 Ga komatiites // Geochim. Cosmochim. Acta. 2016. V. 180. P. 227-253.

24. Watson E.B. Two-liquid partition coefficients experimental data and geochemical implications // Contrib. Mineral. Petrol. 1976. V. 56. P. 119-134. 